\title{
Simultaneous polyhydroxyalkanoates and rhamnolipids production by Thermus thermophilus HB8
}

\author{
Anastasia A Pantazaki ${ }^{1 *}$, Christos P Papaneophytou ${ }^{1}$ and Dimitra A Lambropoulou²
}

\begin{abstract}
The ability of Thermus thermophilus HB8 to produce simultaneously two environmentally-friendly biodegradable products, polyhydroxyalkanoates (PHAs) and rhamnolipids (RLs), using either sodium gluconate or glucose as sole carbon source, was demonstrated. The utilization of sodium gluconate resulted in higher levels of PHAs and RLs production than when glucose was used as sole carbon source. The initial phosphate concentration (as $\mathrm{PO}_{4}{ }^{3-}$ ) influences both PHAs and RLs productions that were increased during cultivation time. PHAs accumulation was enhanced (> $300 \mathrm{mg} / \mathrm{L}$ ) after $72 \mathrm{~h}$ of cultivation in an initial $\left[\mathrm{PO}_{4}{ }^{3}\right]$ of $25 \mathrm{mM}$, while RLs production (> $200 \mathrm{mg} / \mathrm{L}$ ) was started after $35 \mathrm{~h}$ and continued until $72 \mathrm{~h}$ of cultivation, in a phosphate-limited medium containing initially 5 $\mathrm{mM}$ of $\left[\mathrm{PO}_{4}{ }^{3-}\right]$. In addition, the combine effect of initial $\left[\mathrm{PO}_{4}{ }^{3-}\right]$ and cultivation time on biomass, PHAs and RLs production was evaluated from $2 \mathrm{D}$ contour plots. The results revealed that low initial phosphate concentrations (up to $5 \mathrm{mM}$ ) and long incubation time $(72 \mathrm{~h}$ ) promoted RLs biosynthesis while higher initial phosphate concentrations (up to $25 \mathrm{mM}$ ) where favorable for biomass and PHAs production. The molecular composition of the produced bio-products was identified. The accumulated PHAs were co-polymers which mainly consisted of 3hydroxydecanoate (3HD) as resulted by gas chromatography (GC) analysis. The secreted RLs were extracted and their total mixture contained both mono- and di- RLs identified by thin-layer chromatography (TLC). Moreover, the molecular composition of the produced RLs characterized in details by LC-MS analysis showed a plethora of diversity including mono-, and di-RLs, di-rhamno-monolipidic congeners differing in the length of the lipidic chain, which additionally were found to be saturated or unsaturated in some cases.
\end{abstract}

Keywords: polyhydroxyalkanoates (PHAs), rhamnolipids (RLs), phosphate limitation, Thermus thermophilus HB8

\section{Introduction}

A wide variety of microorganisms accumulate polyhydroxyalkanoic acids (PHAs), mainly polyhydroxybutyrate (PHB), as metabolic storage materials, which are deposited as intracellular water-insoluble inclusions (Griebel et al. 1968,; Rehm and Steinbüchel 1999). Most fluorescent Pseudomonads strains belonging to rRNA homology group I, are able to synthesize and accumulate large amounts of PHAs consisting of various 3-hydroxy fatty acids with carbon chain lengths ranging from 6 to 14 carbon atoms (medium chain length-mcl) as carbon and energy storage compounds (Huisman et al. 1989,). The

\footnotetext{
* Correspondence: natasa@chem.auth.gr

'Laboratory of Biochemistry, Dept. of Chemistry, Aristotle University of

Thessaloniki, 54124 Thessaloniki, Greece

Full list of author information is available at the end of the article
}

composition of PHAs depends on the PHA synthases (polymerases) (PhaC), the key enzymes for PHA biosynthesis, the carbon source and the metabolic routes involved (Rehm 2003,; Rehm and Steinbüchel 1999). Purified mcl-PHA synthases, from $P$. aeruginosa exhibit in vitro enzyme activity with (R)-3-hydroxydecanoylCoA as substrate (Amara and Rehm 2003,; Qi et al. 2000,; Ren et al. 2000,). $\beta$-Oxidation is the main pathway for mcl-PHA biosynthesis when fatty acids are used as carbon sources, while de novo biosynthesis of fatty acids is the main route during growth on carbon sources which are metabolized to acetyl coenzyme A (acetyl-CoA), such as gluconate, acetate, or ethanol (Rehm et al. 2001). Besides the intracellular accumulation of PHAs, P. aeruginosa is capable to produce various exo-products, such as rhamnolipids (RLs), which

\section{SpringerOpen $^{\circ}$}

(C) 2011 Pantazaki et al; licensee Springer. This is an Open Access article distributed under the terms of the Creative Commons Attribution License (http://creativecommons.org/licenses/by/2.0), which permits unrestricted use, distribution, and reproduction in any medium, provided the original work is properly cited. 
are expressed in the onset of the stationary phase (Déziel et al. 1996).

RLs are glycolipidic bio-surfactants, which reduce water surface tension and emulsify oil. The RLs produced by $P$. aeruginosa in liquid cultures are mainly rhamnosyl- $\beta$-hydroxydecanoyl- $\beta$-hydroxydecanoate (mono-RL) and rhamnosyl-rhamnosyl- $\beta$-hydroxydecanoyl- $\beta$-hydroxydecanoate (di-RLs) (Ochsner and Reiser 1995,). RL biosynthesis proceeds through transfer of two rhamnose moieties from TDP-L-rhamnose (Maier and Soberón-Chávez 2000,). For the synthesis of mono-RL, the enzyme rhamnosyl-transferase 1 (Rt 1) catalyses the rhamnose transfer to $\beta$-hydroxydecanoyl- $\beta$-hydroxydecanoate, while rhamnosyl-transferase 2 (Rt 2) synthesizes di-RL from TDP-L-rhamnose and mono-RL. Genes for biosynthesis, regulation and induction of the Rt 1 enzyme are organized in tandem in the rhlABRI gene cluster (Ochsner and Reiser 1995,). The gene rhlC encoding the Rt 2 enzyme has been described (Rahim et al. 2001,), and is homologous to rhamnosyl-transferases involved in lipopolysaccharide biosynthesis. Some evidence was recently provided that RhlA is involved in synthesis of 3-(3-hydroxyalkanoyloxy)alkanoic acids (HAAs) (Déziel et al. 2003,); however, it still remains unclear whether the PHA synthase is capable of catalyzing the synthesis of HAAs, which has been previously postulated (Campos-Garcia et al. 1998,; Déziel et al. 2003,; Rehm et al. 2001).

The expression of phaG gene, encoding transacylase from $P$. putida in mutants indicated that PhaG catalyzes diversion of intermediates of fatty acid de novo biosynthesis towards PHA biosynthesis, and in the transacylase-mediated PHA biosynthesis route from gluconate, PhaG is the only linking enzyme between fatty acid de novo biosynthesis and PHA biosynthesis. In addition, expression of the $\beta$-ketoacyl reductase gene $r h l G$ from $P$. aeruginosa in mutants revealed that RhlG catalyzes diversion towards RL biosynthesis (Campos-Garcia et al. 1998,). RhlG is thought to catalyze the NADPH-dependent reduction of $\beta$-ketodecanoyl-ACP, which is an intermediate of fatty acid de novo biosynthesis, resulting in $\beta$-hydroxydecanoyl-ACP, a putative precursor for RL biosynthesis. The proposed pathways for mcl-PHA and RLs biosynthesis suggested that both biosynthesis pathways are competitive (Rehm et al. 2001).

While the opportunistic pathogen $P$. aeruginosa has traditionally been considered the primary PHAs and RLs-producing microorganism, however it appears that the ability to produce PHAs and especially RLs (AbdelMawgoud et al. 2010,) is in fact restricted to a limited number of bacterial species. Since there are a plethora of applications for both metabolites PHAs (Zinn et al. 2001,; Valappil et al. 2006,) and RLs (Abdel-Mawgoud et al. 2010,) a low cost production would be very challenging. A novel approach for reducing their production costs was also reported for the simultaneous production of the intracellular PHAs and the extracellular RLs (Hori et al. 2002,). PHAs production was reported using the remaining oil from RL production (Füchtenbusch et al. 2000,). This approach was adopted to reduce PHA production cost by using the remaining carbon source for RL production. Palm oil, one of the typical plant oils, was also used as the sole carbon source for the simultaneous production of both products (Marsudi et al. 2008).

Bio-surfactants are produced by certain bacteria, yeasts, and filamentous fungi during cultivation on various carbon sources, in particular during growth on hydrophobic substances such as hydrocarbons leading to the assumption that biosurfactants serve to emulsify the hydrocarbons in the growth medium thus facilitating their uptake. A correlation between surfactant production and growth on water-insoluble substrates was shown (Itoh and Suzuki 1972). RLs are usually produced by $P$. aeruginosa also in media containing water-soluble carbon sources such as glucose, glycerol, mannitol, and ethanol as a carbon source, particularly, when the cells become limited for nitrogen (Guerra-Santos et al. 1986; Mulligan and Gibbs 1993,; Robert et al. 1989,; Sim et al. 1997,; Wagner et al. 1983) indicating that they may serve other roles besides being involved in solubilizing hydrophobic substrates; nevertheless, the final surfactant concentration was lower than that obtained when $n$ alkanes and vegetable oils were the carbon substrates (Syldatk et al. 1985,; Robert et al. 1989). The carbon source influences bio-surfactant synthesis by either induction or repression. An induction of glycolipid production by $P$. aeruginosa SB30, when $n$-alkanes were added to the medium was reported (Chakrabarty 1985,). Catabolic repression of bio-surfactant synthesis by glucose, acetate, and tricarboxylic acids was also observed (Hauser and Karnovsky 1958,, 1954). When P. aeruginosa UG2 was grown on hydrophobic substrates such as corn oil, lard, and long chain alcohols, production was around 100-165 mg of rhamnolipid/g substrate, whereas when hydrophilic substrates such as glucose and succinic acid were used, only $12-36 \mathrm{mg} / \mathrm{g}$ substrate was obtained (Mata-Sandoval et al. 1999).

Polyhydroxyalkanoates (PHAs) are intracellular storage compounds of carbon and energy that are produced by many bacteria in the form of inclusion bodies (Anderson and Dawes 1990,). PHAs have attracted commercial biotechnological interest because of their biodegradability and biocompatibility (Reddy et al. 2003).

PHA biosynthesis by the thermophilic bacterium $T$. thermophilus HB8 has been previously reported (Pantazaki et al. 2003,) while the soluble PHA synthase (Pantazaki et al. 2003), and a $\beta$-ketoacyl-CoA thiolase 
(Pantazaki et al. 2005), were purified from sodium gluconate-grown cells. In addition, PHAs production by $T$. thermophilus HB8 using whey as sole carbon source was also reported (Pantazaki et al. 2009). Recently, it was also demonstrated that $T$. thermophilus secreted RLs, when grown in the presence of insoluble substrates such as sunflower seed oil or oleic acid. The produced RLs have been identified by several methods e.g the orcinol method, Thin Layer Chromatography (TLC) and Attenuated Total Reflection Infrared (ATR-FTIR) spectroscopy and LC-(ESI)-MS (Pantazaki et al. 2010).

In this study we report the simultaneous production of both metabolites PHAs accumulated intra-cellularly and RLs secreted extra-cellularly by employing T. thermophilus HB8, as an approach to turn to advantage from the carbon source used extensively for the production of high added value bio-products from wastes aiming to obtaining the reduction of production cost. In this concept, this study specifically focused in finding the optimum growth condition by examining the combine effect of cultivation time and initial $\left[\mathrm{PO}_{4}{ }^{3-}\right]$ on the simultaneous production of these metabolites to increase their production. The identification of the molecular composition of the produced PHAs and bio-surfactants RLs was also evaluated by GC chromatography and thin-layer chromatography (TLC)/LC-MS analysis respectively.

\section{Materials and methods}

\section{Bacterial strain and growth}

T. thermophilus HB8 (DSM 579) was grown in a rich medium (DSMZ-74) containing per liter: $8 \mathrm{~g}$ tryptone, $4 \mathrm{~g}$ yeast extract, and $2 \mathrm{~g} \mathrm{NaCl}$. For PHAs and RLs production, cultivation was carried out in $2 \mathrm{~L}$ Erlenmeyer flasks containing $700 \mathrm{~mL}$ mineral salt medium (MSM) containing per liter: 1 $\mathrm{mM} \mathrm{KH}_{2} \mathrm{PO}_{4}, 25 \mathrm{mM} \mathrm{Na}_{2} \mathrm{HPO}_{4} .12 \mathrm{H}_{2} \mathrm{O}, 0.05 \mathrm{~g} \mathrm{NH}_{4} \mathrm{Cl}, 10$ g NaCl, $15 \mathrm{mg} \mathrm{CaCl}_{2}, 123 \mathrm{mg} \mathrm{MgSO}_{4} .7 \mathrm{H}_{2} \mathrm{O}, 6 \mathrm{~mL}$ of a mineral solution (Pantazaki et al. 2003). T. thermophilus HB8 cultures were grown in the presence of the selected carbon source at $75^{\circ} \mathrm{C}$. Glucose $(2 \% \mathrm{w} / \mathrm{v})$ or sodium gluconate $(1.5 \% \mathrm{w} / \mathrm{v})$ were used as sole carbon sources.

To investigate the influence of the initial $\left[\mathrm{PO}_{4}{ }^{3-}\right]$ on both PHAs and RLs production, T. thermophilus was grown in MSM containing per liter: $2 \mathrm{~g} \mathrm{NH}_{4} \mathrm{Cl}, 10 \mathrm{~g}$ $\mathrm{NaCl}, 15 \mathrm{mg} \mathrm{CaCl}, 123 \mathrm{mg} \mathrm{MgSO}_{4} \cdot 7 \mathrm{H}_{2} \mathrm{O}, 6 \mathrm{~mL}$ of a mineral solution (Pantazaki et al. 2003) and one of the following initial phosphate concentrations: 0.5, 5, 10, 25 and $50 \mathrm{mM}$. Phosphate concentration was adjusted by the addition of the proper amount of a $0.5 \mathrm{M}$ phosphate buffer, pH 7.2. Sodium gluconate was used as sole carbon source at a concentration of $1.5(\% \mathrm{w} / \mathrm{v})$.

\section{Biomass and PHA content determination in cells}

During cultivation aliquots of $100 \mathrm{~mL}$ were removed from each of the cultures, at various time intervals, and were centrifuged at $6,800 \times \mathrm{g}$ for $15 \mathrm{~min}$ to separate the biomass from the supernatants. Biomass was used for the determination of PHAs content in the cells, while the supernatants obtained were destined for RLs determination. Cell concentration, defined as cell dry weight (CDW) per liter of culture broth in each time interval during cultivation, was determined by filtrating $10 \mathrm{~mL}$ of culture broth using tarred membranes filters (Millipore, $0.45 \mu \mathrm{m}$ filters), washing cell pellets, drying at $80^{\circ}$ $\mathrm{C}$ for $48 \mathrm{~h}$, and weighing dry cells as previously reported (Pantazaki et al. 2009). The content of polyester in the cells was calculated as the ratio of weight of extracted PHAs to the cell dry weight from which PHAs were extracted.

\section{PHAs characterization}

The monomer composition of the accumulated PHAs as well their content in the cells, were determined by gas chromatography (GC) as previously reported (Braunegg et al. 1978). For this lyophilized T. thermophilus HB8 cells $(10 \mathrm{mg})$ were subjected to methanolysis in the presence of $15 \%$ (v/v) sulfuric acid (Braunegg et al. 1978), for extraction of polyester and its transformation in the corresponded 3-hydroxyalkanoic methyl esters. Gas chromatography was performed with a Varian 3300 gas chromatograph equipped with an OV-351 capillary column (15 m × $0.53 \mathrm{~mm}$; OHIO VALLEY Capillaries, 115 Industry Road, Marietta, $\mathrm{OH} 45750$, U.S.A.) and a flame ionization detector. Two microliters of the organic phase was injected in the column. Nitrogen $(1 \mathrm{~mL} / \mathrm{min})$ was used as the carrier gas. The temperature of the injector and detector were 200 and $230^{\circ} \mathrm{C}$, respectively. A temperature program was used for efficient separation of the esters $\left[60^{\circ} \mathrm{C}\right.$ for $1 \mathrm{~min}$, temperature increase $8^{\circ} \mathrm{C} /$ min until $160^{\circ} \mathrm{C}$, temperature increase $25^{\circ} \mathrm{C} / \mathrm{min}$ to $230^{\circ}$ $\mathrm{C}\left(230^{\circ} \mathrm{C}\right.$ for $\left.\left.1 \mathrm{~min}\right)\right]$. Under these conditions, the retention times (in minutes) of the different 3-hydroxyalkanoic acid methyl ester standards were as follows: C4, 3.18; C5, 4.16; C6, 5.24; C7, 7.11; C8, 7.95; C9, 9.46; C10, 10.53; C11: 11.9; C12, 13.2 (CX represents the 3hydroxyalkanoic acid methyl ester with a chain length of $\mathrm{X}$ carbon atoms).

\section{Extraction and analysis of RLs}

Produced RLs were extracted from the culture supernatants, as previously described (Hori et al. 2002,) and quantified by the colorimetric orcinol method (Koch et al. 1991,). Three independent samples were extracted for each cultivation time to monitor the reproducibility of the rhamnolipids extraction procedure. RLs concentration was calculated by a coefficient of 3.4 , obtained from the correlation of pure rhamonlipids/rhamnose $(1.0 \mathrm{mg}$ of rhamnose corresponds approximately to 3.4 mg of rhamnolipids) (Pearson et al. 1997). RLs were 
analyzed by thin-layer chromatography (TLC) on silica gel plates (Kieselgel 60/Kieselgur F254; Merck, Darmstadt, Germany). Samples were spotted on the plates and separated using a mobile phase consisting of $80 \%$ $(\mathrm{v} / \mathrm{v})$ chloroform, 18\% (v/v) methanol and 2\% (v/v) acetic acid. TLC plates were sprayed with a thymol spray reagent $\left[0.5 \mathrm{~g}\right.$ thymol in EtOH-conc. $\mathrm{H}_{2} \mathrm{SO}_{4}(95: 5$, $\mathrm{v} / \mathrm{v})$ ]; after spraying plates were heated for $20 \mathrm{~min}$ at 100 to $120^{\circ} \mathrm{C}$ for $20 \mathrm{~min}$, and the RLs appeared as pink spots (Schenk et al. 1995).

\section{Determination of glucose and phosphate concentration}

Remaining glucose concentration in culture media was measured by an enzymatic colorimetric method using a commercially available kit (Sigma GAG020). Glucose is oxidized to gluconic acid and hydrogen peroxide by glucose oxidase. Hydrogen peroxide reacts with $o$-dianisidine in the presence of peroxidase to form a colored product. Oxidized $o$-dianisidine reacts with sulfuric acid to form a more stable colored product. The intensity of the pink color measured at $540 \mathrm{~nm}$ is proportional to the original glucose concentration.

Determination of inorganic phosphate (as $\mathrm{PO}_{4}{ }^{3-}$ ) was performed with the conventional colorimetric method (Fiske and SubbaRow 1925).

\section{LC-MS analysis of RLS}

ESI-MS in both negative and positive mode was performed using an Agilent G2455A ion trap mass spectrometer equipped with Agilent software. The collected samples of RLs were dissolved in $\mathrm{MeOH} /$ water $(0.1 \%$ Formic acid) and infused in the ESI source with flow rate of $100 \mu \mathrm{L} / \mathrm{min}$. ESI-MS spectra (positive or negative mode) were acquired from m/z 50-1200 for $2.5 \mathrm{~min}$. Operating conditions were as follows: accumulation time, $300 \mathrm{~ms}$; dry temperature, $350 \mathrm{C}$; capillary voltage, $3500 \mathrm{~V}$; nebulizer, $30 \mathrm{psi}$; dry gas, helium at $8 \mathrm{~L} / \mathrm{min}$.

\section{Results}

\section{Effect of carbon source on simultaneous PHAs and RLs} production by $T$. thermophilus HB8

The ability of $T$. thermophilus to produce simultaneously PHAs and RLs was initially tested in MSM containing either glucose $(2 \% \mathrm{w} / \mathrm{v})$ or sodium gluconate $(1.5 \% \mathrm{w} / \mathrm{v})$ as sole carbon source while the initial phosphate concentration was adjusted at approximately 36 $\mathrm{mM}$ (see Material and Methods section). Glucose was selected since is the most commonly used sugar substrate in microbial cultivations, while sodium gluconate derived from glucose, its metabolic precursor, in which glucose is transformed via Entner-Doudoroff pathway by glucose dehydrogenase with the $\mathrm{NAD}(\mathrm{P})^{+}$reduction. In addition, the utilization of glucose by Pseudomonas for the RLs (Guerra-Santos et al. 1986,) or PHAs (Huijberts et al. 1992,) production has been previously reported. Moreover, glucose is an attractive carbon source because it can be obtained by hydrolyzing cheap raw materials such corn starch (Lee 1996,) or organic waste from the food industry (Rusendi and Sheppard 1995).

Each of the tested carbon sources assured the simultaneous production of PHAs and RLs, whereas biomass was increasing during cultivation as illustrated in Figure 1. Similarly, PHAs and RLs productions in both cultures increased during cultivation process reaching their maximum values at the end of the culture (after $72 \mathrm{~h}$ ).

The utilization of glucose by $T$. thermophilus resulted in a high biomass production reaching at $1288 \mathrm{mg} / \mathrm{L}$ as shown in Figure 1a, while at the same time PHAs and
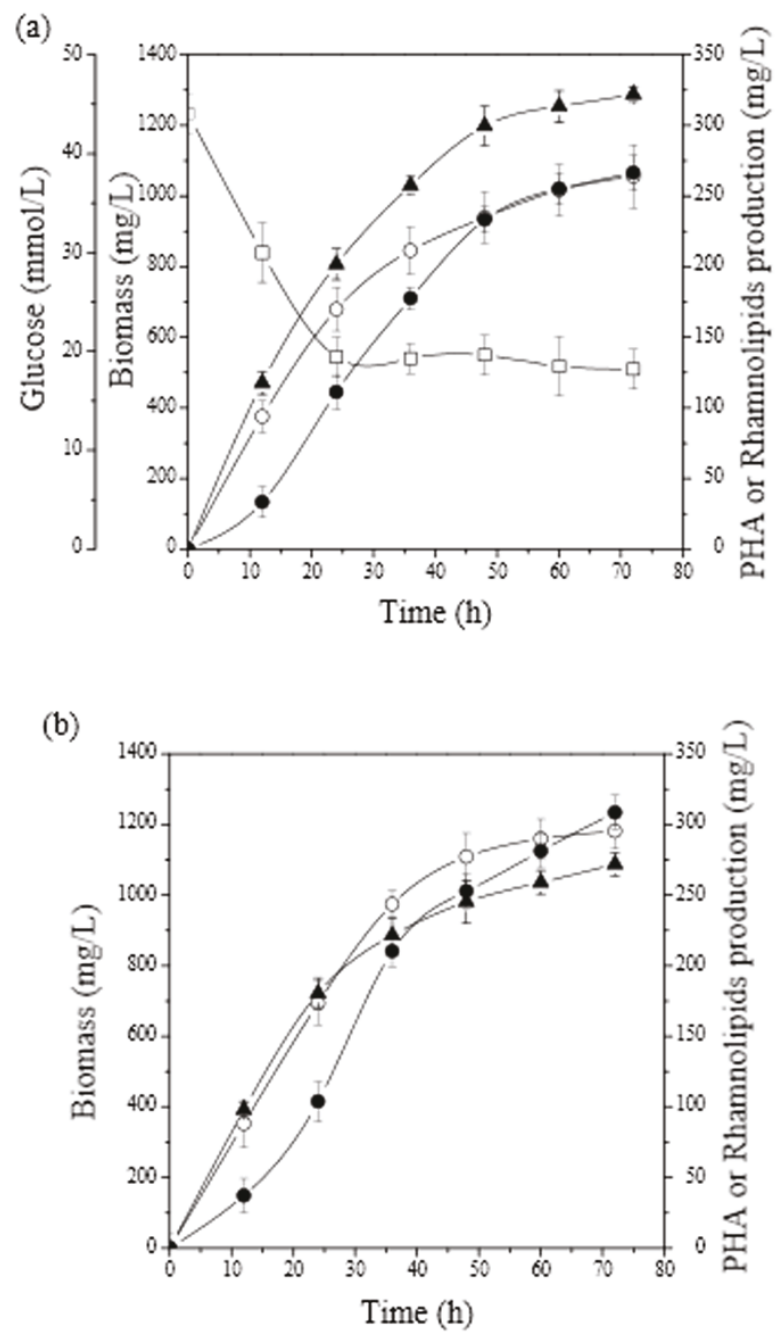

Figure 1 Simultaneous PHAs and RLs production by $T$. thermophilus HB8 in MSM containing glucose (a) or sodium gluconate (b) as sole carbon source. Symbols: biomass (closed triangle); PHAs production (closed circles); RLs production (open circles) and glucose concentration (open squares) 
RLs production were $266 \mathrm{mg} / \mathrm{L}$ and $189 \mathrm{mg} / \mathrm{L}$ respectively. A sharp decrease of glucose concentration was recorded until $20 \mathrm{~h}$ of growth; while at prolongated cultivation glucose remained equal to $20 \mathrm{mmole} / \mathrm{L}$ until 72 h. However, the value of exhausted glucose that was two thirds of the initial value still remained stable because of the conversion of glucose into acidic compounds such as gluconic acid. It is well known that the cultivation of certain kinds of bacteria on glucose decreases the $\mathrm{pH}$ value of the culture broth due to acid production ending in acidification of the culture broth, which might inhibit bacterial growth and might affect also the increase of the PHAs content (Hori et al. 2002).

On the other hand, although the supplementation of MSM with sodium gluconate led to a lower biomass production $(1087 \mathrm{mg} / \mathrm{L})$, both PHAs and RLs production were higher $(308 \mathrm{mg} / \mathrm{L}$ and $211 \mathrm{mg} / \mathrm{L}$ respectively) (Figure 1b) than that obtained when glucose was used as sole carbon source. Thus, sodium gluconate was chosen to be tested for the simultaneous PHAs and RLs production in the experiment for optimization of phosphate concentration.

In addition, polymer composition was found to be affected by the carbon sources used. More specific, glucose consumption led to the production of a copolymer containing as monomers 3HD (60.2\%), 3HO (20.8 mol $\%)$, 3HB (10.5 mol\%), and 3HDD (8.5 mol\%). When sodium gluconate was utilized as sole carbon source, a copolymer containing both $\mathrm{scl}$ and mcl HAs was also accumulated. This copolymer was consisted of 3HD (65 mol\%), 3HO (23 mol\%) as majors constituents and $3 \mathrm{HB}$ (4 mol\%) and $3 \mathrm{HV}(8 \mathrm{~mol} \%)$ as minor monomer units.

\section{Effect of initial phosphate concentration $\left[\mathrm{PO}_{4}{ }^{3-}\right]$ on simultaneous PHAs and RLs production by $T$. thermophilus}

Phosphate is a vital component of many cell structures including nucleic acids, phospholipids, proteins and coenzymes. Phosphate compounds transformations are involved in cellular energetic, and the direction of many biochemical processes in microorganisms is strongly dependent on the presence of phosphates (Dawes 1986,; Kulaev 1985). Thus, following the preliminary experiments in which we investigated the influence of carbon source on PHAs and PLs production in culture media containing initially $36 \mathrm{mM}$ of phosphates we examine the influence of various initial phosphate concentrations (ranging from $0.5-50 \mathrm{mM}\left[\mathrm{PO}_{4}{ }^{3-}\right]$ on both products synthesis. Sodium gluconate was chosen as sole carbon source since it leads to the higher PHAs and RLs production.

The results revealed that all initial $\left[\mathrm{PO}_{4}{ }^{3-}\right]$ tested sustained the growth of T. thermophilus, and PHAs and PLs synthesis as well, while in all cultures the values of biomass, PHAs and RLs production recorded after 72 $\mathrm{h}$ of cultivation exhibited to have still an increasing tendency. In addition, Table 1 summarizes the results of cell growth (measured as CDW), PHAs and RLs production, PHAs and RLs yields (as percentage of CDW) and PHAs composition at this time of cultivation.

Phosphorus was limited after $10 \mathrm{~h}$ of cultivation in the culture medium containing $0.5 \mathrm{mM}$ of initial $\left[\mathrm{PO}_{4}{ }^{3-}\right]$ (Figure 2a), resulting in both the lowest cell and PHAs concentration $(667 \mathrm{mg} / \mathrm{L}$ and $164 \mathrm{mg} / \mathrm{L}$, respectively) recorded in this experiment (Table 1 ). In addition, PHAs content was only $24 \%$ of CDW. In contrast, phosphate limitation resulted in the highest RLs production and yield, reaching $230 \mathrm{mg} / \mathrm{L}$ and $34.48 \%$ respectively, as illustrated in Table 1. Phosphorus was early limited, approximately after $15 \mathrm{~h}$ of cultivation, in the culture medium containing initially $5 \mathrm{mM}$ of $\left[\mathrm{PO}_{4}{ }^{3-}\right]$ resulting in a biomass production of $840 \mathrm{mg} / \mathrm{L}$ (Figure 2b). PHAs production was increased with the increase of cultivation time reaching a maximum value of $258 \mathrm{mg} / \mathrm{L}$ after $72 \mathrm{~h}$ of cultivation. On the other hand, RLs production reached a plateau after $30 \mathrm{~h}$ of cultivation and a maximal value of $204 \mathrm{mg} / \mathrm{L}$ (Figure 2b).

Table 1 Effect of the initial phosphate concentration in T. thermophilus growth, rhamnolipids production and PHAs production and composition ${ }^{a}$

\begin{tabular}{|c|c|c|c|c|c|c|c|c|c|}
\hline \multirow[t]{2}{*}{$\begin{array}{c}\text { Phosphate } \\
\text { concentration (mM) }\end{array}$} & \multirow[t]{2}{*}{$\begin{array}{c}\text { Biomass }\left(C D W^{b}\right) \\
(\mathrm{mg} / \mathrm{L})\end{array}$} & \multirow[t]{2}{*}{$\begin{array}{l}\text { Rhamnolipids } \\
\text { (mg/L) }\end{array}$} & \multirow[t]{2}{*}{$\begin{array}{l}\text { Yield of Rhamnolipids } \\
\text { (\% DCW) }\end{array}$} & \multirow[t]{2}{*}{$\begin{array}{l}\text { PHA } \\
\text { (mg/L) }\end{array}$} & \multirow[t]{2}{*}{$\begin{array}{l}\text { PHA content }(\% \\
\text { DCW) }\end{array}$} & \multicolumn{4}{|c|}{$\begin{array}{c}\text { monomer composition (\% } \\
\text { mole) }\end{array}$} \\
\hline & & & & & & $\begin{array}{l}\mathrm{HB} \\
\left(\mathrm{C}_{4}\right)\end{array}$ & $\begin{array}{l}\mathrm{HV} \\
\left(\mathrm{C}_{5}\right)\end{array}$ & $\begin{array}{l}\mathrm{HO} \\
\left(\mathrm{C}_{8}\right)\end{array}$ & $\begin{array}{l}\mathrm{HD} \\
\left(\mathrm{C}_{10}\right)\end{array}$ \\
\hline 0.5 & 667 & 230 & 34.48 & 164 & 24.28 & 4.4 & 8.5 & 26.7 & 60.4 \\
\hline 5 & 840 & 204 & 24.29 & 258 & 30.73 & 4.6 & 7.9 & 26.2 & 61.3 \\
\hline 10 & 911 & 202 & 22.17 & 298 & 32.70 & 4.2 & 8.8 & 25.9 & 61.1 \\
\hline 25 & 1040 & 161 & 15.48 & 362 & 34.81 & 5.3 & 8.1 & 26.8 & 59.8 \\
\hline 50 & 1120 & 118 & 10.54 & 228 & 20.36 & 4.9 & 8.3 & 25.4 & 61.1 \\
\hline
\end{tabular}

\footnotetext{
${ }^{\mathrm{a}}$ Measures were obtained after $72 \mathrm{~h}$ of cultivation.

b CDW: Cell Dry Weight

Note: all experiments were performed twice while all data are means of triplicates determinations.
} 

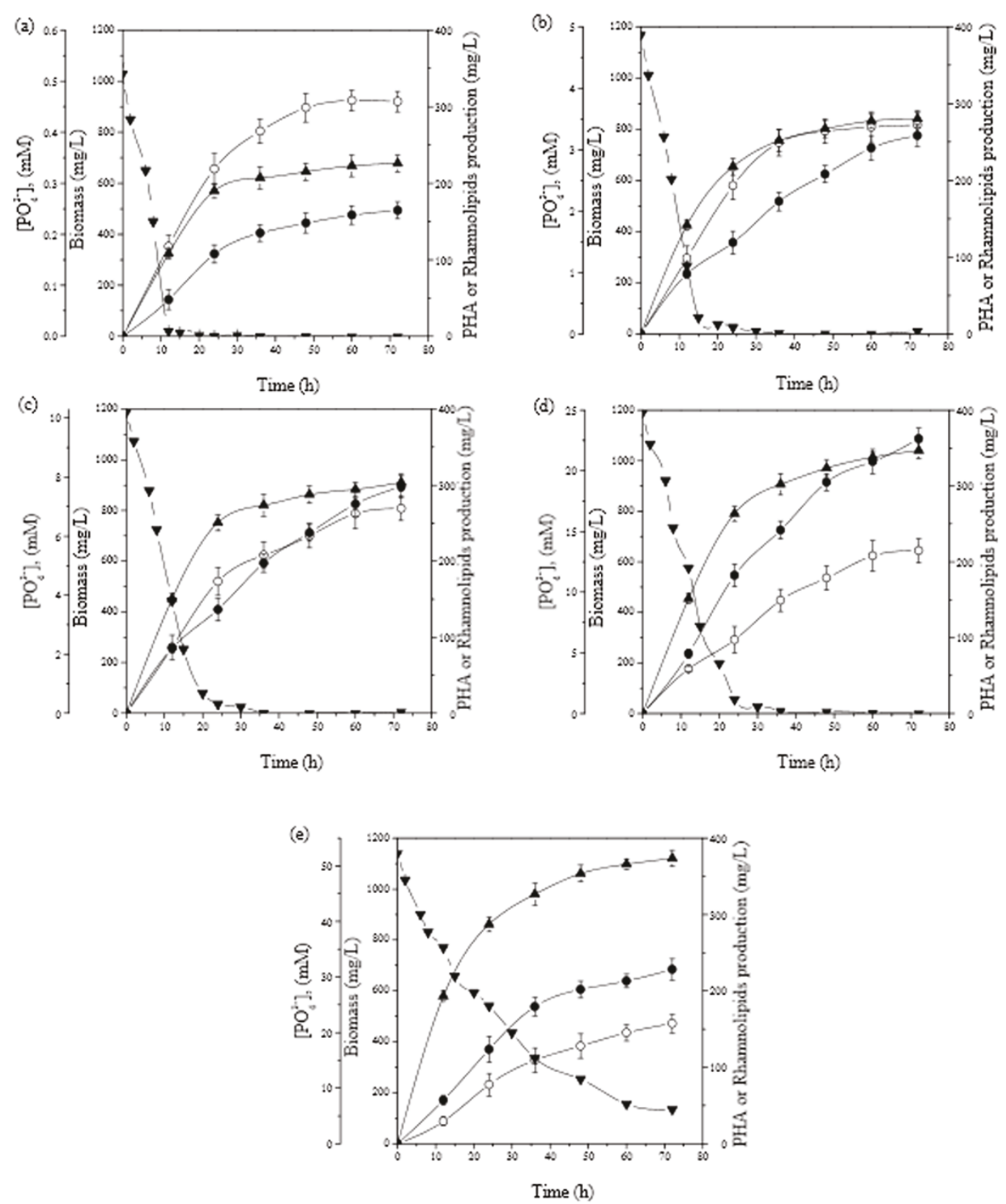

Figure 2 Effect of the initial $\left[\mathrm{PO}_{4}{ }^{3-}\right]$ on $T$. thermophilus $\mathrm{HB} 8$ growth, PHAs accumulation and RLs synthesis. T. thermophilus was grown in MSM containing sodium gluconate $(1.5 \% \mathrm{w} / \mathrm{v})$ as sole carbon source and one of the following initial $\left[\mathrm{PO}_{4}{ }^{3-}\right] 0.5 \mathrm{mM}(\mathrm{a}) ; 5 \mathrm{mM}$ (b); $10 \mathrm{mM}$ (c); 25 $\mathrm{mM}$ (d) and $50 \mathrm{mM}$ (e). Symbols: Biomass (CDW) (closed triangles); PHAs production (closed circles); RLs (open circles) and [ $\left.\mathrm{PO}_{4}{ }^{3}\right]$ (reversed closed triangles).

Amongst the cultures tested, biomass production was significant higher, in the culture medium containing 10 $\mathrm{mM}$ of $\left[\mathrm{PO}_{4}{ }^{3-}\right]$, which were exhausted approximately after $20 \mathrm{~h}$ of cultivation (Figure 2c). Both PHAs and RLs production increased during cultivation reaching at 298 $\mathrm{mg} / \mathrm{L}$ and $202 \mathrm{mg} / \mathrm{L}$, respectively at the end of the culture (72 h). PHAs and RLs yields (as \% of CDW) were $22.17 \%$ and $32.70 \%$, respectively (Table 1 ). In the culture containing $25 \mathrm{mM}$ of initial $\left[\mathrm{PO}_{4}{ }^{3-}\right]$, cell concentration reached the value of $1040 \mathrm{mg} / \mathrm{L}$ after $72 \mathrm{~h}$ of cultivation 
(Figure 2d). Phosphate limitation was achieved after 24 $\mathrm{h}$ of cultivation (at the beginning of the stationary phase) resulting in high PHAs production. When phosphate limitation occurred, the rate of cell growth was decreased while PHAs concentration increased rapidly from 110 to $362 \mathrm{mg} / \mathrm{L}$. In contrast, RLs production as well as its yield (\% of CDW) were significant lower (161 $\mathrm{mg} / \mathrm{L}$ and $15.5 \%$, respectively) compared to that recorded in culture medium containing $0.5 \mathrm{mM}$ of initial $\left[\mathrm{PO}_{4}{ }^{3-}\right]$.

In contrast, phosphate was not limited in culture media containing initially $50 \mathrm{mM}$ of $\left[\mathrm{PO}_{4}{ }^{3-}\right]$, even after $72 \mathrm{~h}$ of cultivation, resulting in the highest cell concentration, $1120 \mathrm{mg} / \mathrm{L}$ as illustrated in Figure 2e. However, PHAs accumulation was almost 1.3 and 1.5 times respectively lower $(228 \mathrm{mg} / \mathrm{L})$ compared to the PHAs production recorded in culture medium containing 10 or $25 \mathrm{mM}$ of phosphate. RLs production was increasing almost linearly during growth reaching at $118 \mathrm{mg} / \mathrm{L}$ after $72 \mathrm{~h}$ of cultivation. However, RLs production and its yield were 2 and 3 times respectively lower than that obtained in culture medium containing initially $0.5 \mathrm{mM}$ of $\left[\mathrm{PO}_{4}{ }^{3-}\right]$ (Table 1$)$. Moreover, the initial $\left[\mathrm{PO}_{4}{ }^{3-}\right]$ did not significantly influence the polymer composition as illustrated in Table 1.

\section{Dependence of simultaneous PHAs and RLs production from cultivation time and initial phosphate concentration $\left[\mathrm{PO}_{4}{ }^{3-}\right]$}

For the simultaneous PHAs and RLs production, the combine effect of both the cultivation time and the initial $\left[\mathrm{PO}_{4}{ }^{3-}\right]$ on biomass was examined, and we designed contour plots using the Minitab V15 software. Figure 2a illustrates the combine effect of both the cultivation time and the initial $\left[\mathrm{PO}_{4}{ }^{3-}\right]$ on biomass production. As it can be seen, biomass increased with both the augmentation of the initial $\left[\mathrm{PO}_{4}{ }^{3-}\right]$ and the cultivation time. All contours, which represent regions of biomass amplitude (defined in the inset of Figure 3a) exhibited a tendency of convergence at a concrete point that corresponds in the intersection of $50 \mathrm{mM}$ of $\left[\mathrm{PO}_{4}{ }^{3-}\right]$ and 72 $\mathrm{h}$ of cultivation time. These results indicated that whether the upper $\left[\mathrm{PO}_{4}{ }^{3-}\right]$ would have increased more, then the contours would have a convergence at a point. Thus, by increasing further the $\left[\mathrm{PO}_{4}{ }^{3-}\right]$ up to $50 \mathrm{mM}$, biomass seems to come on at a higher value after a more prolonged time of cultivation.

Similarly, the combine effect of both the initial $\left[\mathrm{PO}_{4}{ }^{3-}\right]$ and the cultivation time on PHAs production is shown in Figure $3 \mathrm{~b}$. In this graph, all contours represent regions of PHAs production amplitude (defined in the inset of Figure $3 \mathrm{~b}$ ). In these contours, PHAs production increased (> $300 \mathrm{mg} / \mathrm{L}$ ) with the increase of cultivation time but the convergence of the curves toward the
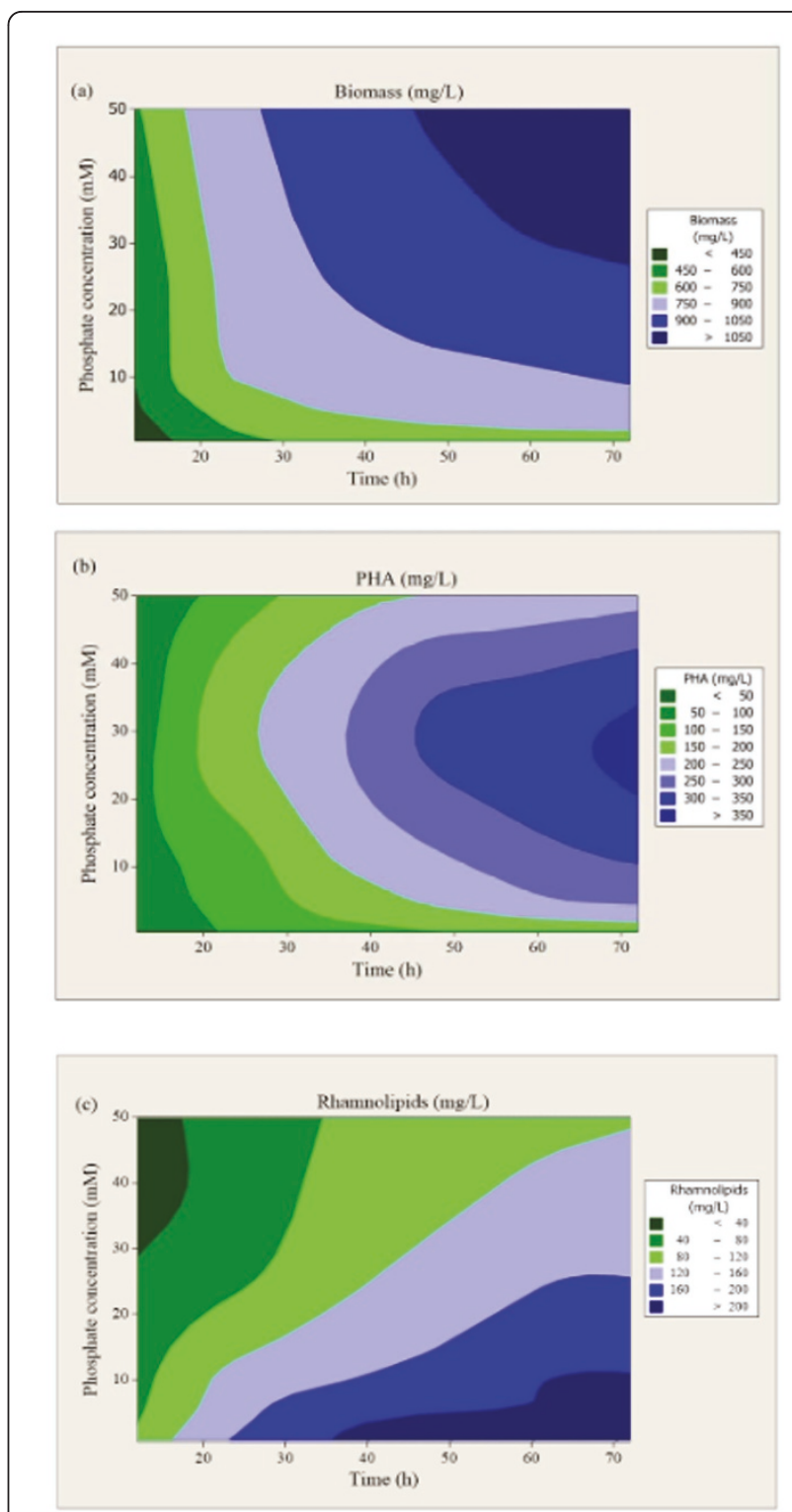

Figure 3 Contour plots of the combine effect of the initial $\left[\mathrm{PO}_{4}{ }^{3-}\right]$ and cultivation time on biomass production (a), PHAs accumulation (b) and RLs synthesis (c) by T. thermophilus HB8.

initial phosphates concentrations of 25-30 mM demonstrated that PHAs production would not be further rise by increasing phosphates concentration above $30 \mathrm{mM}$. This value corresponds to the intersection of the lines at the $30 \mathrm{mM}$ of phosphates concentration and at $72 \mathrm{~h}$ of cultivation time.

Furthermore, the influence of both the initial phosphates concentration and the cultivation time on rhamnolipids synthesis is illustrated in Figure 3c. In this graph, all contours represent regions of rhamnolipids production amplitude (defined in the inset of Figure 3c). As it can be seen rhamnolipids synthesis occurred after 
$35 \mathrm{~h}$ of cultivation and continued until the $72 \mathrm{~h}$ of cultivation, where the $\left[\mathrm{PO}_{4}{ }^{3-}\right]$ is lower than $10 \mathrm{mM}$. RLs concentration increased ( $>200 \mathrm{mg} / \mathrm{L}$ ) with the increase of cultivation time and the simultaneous decrease of the initial phosphate concentration, while high $\left[\mathrm{PO}_{4}{ }^{3-}\right]$ had a negative effect on RLs production.

\section{TLC results}

Biochemical analysis of RLs biosynthesis is confirmed by TLC. The wild type strain of T. thermophilus HB8 make all RL biosynthetic intermediates under the described growth conditions and produces two $\alpha$-thymol positive spots-mainly the slow-migrating spot, which represents di-RLs (Rf 0.125) and secondly the fast-migrating spot representing mono-RLs ( $R f 0.56$ ), in the presence of sodium gluconate. It is queer that in the presence of glucose only di-RLs was detected. This result is probably due to a quantitative difference of sample or a degradation of di-RLs to mono-RLs in the case of sodium gluconate. Ramnose and saponin white were used as sample of reference (data not shown).

\section{LC-MS characterization}

The mixture of RLs was also analyzed by direct infusion of the sample into the mass spectrometer. As described in the Experimental Section, the MS spectra were acquired in both positive and negative ion modes to confirm the structural assignment of the quasi-molecular ion, $[\mathrm{M}+\mathrm{H}]^{+}$in positive ion mode by the corresponding molecular anion $[\mathrm{M}-\mathrm{H}]^{-}$. Assignments of the mass spectra ions were aided by elemental composition calculation results, comparison of structural analogues and available literature (Camilios-Neto et al. 2010,; Camilios Neto et al. 2009,; Déziel et al. 1999,; Haba et al. 2003,; Lotfabad et al. 2010,; Monteiro et al. 2007,; Pantazaki et al. 2010,; Price et al. 2009,; Rooney et al. 2009) as well as acquired knowledge regarding mass spectrometry of related compounds. Table 2 depicts the average spectrum of a RLs-containing sample at $72 \mathrm{~h}$, which was obtained using the infusion method in the positive mode. In most cases, the positive spectra exhibited an $[\mathrm{M}+\mathrm{H}]^{+}$pseudomolecular ion, which was accompanied by a series of adduct ions (i.e. $[\mathrm{M}+\mathrm{Na}]^{+},[\mathrm{M}+\mathrm{K}]$ ${ }^{+},\left[\mathrm{M}-\mathrm{H}+\mathrm{Na}_{2}\right]^{+},\left[\mathrm{M}+\mathrm{H}+\mathrm{CH}_{3}\right]+$ etc.) due to the presence of methanol, water and formic acid into the sample. The spectra were characterized by molecular ions for monoRLs in the mass range from 303-673, di-rhamno-monolipidic congeners from 453-509 and di-RLs from 595 to 792 mass units, respectively. The protonated ions [M $+\mathrm{H}]^{+}$at $\mathrm{m} / \mathrm{z} 447, \mathrm{~m} / \mathrm{z} 587$, and $\mathrm{m} / \mathrm{z} 645$ correspond to mono-RLs Rha- $\mathrm{C}_{8}-\mathrm{C}_{8: 1} /$ Rha- $\mathrm{C}_{8: 1}-\mathrm{C}_{8} /$ Rha- $\mathrm{C}_{12}-\mathrm{C}_{14: 1} /$ Rha$\mathrm{C}_{14}-\mathrm{C}_{12: 1}$ and $\mathrm{Rha}-\mathrm{C}_{14}-\mathrm{C}_{16} / \mathrm{Rha}-\mathrm{C}_{16}-\mathrm{C}_{14}$, respectively. The ions at $\mathrm{m} / \mathrm{z} 621, \mathrm{~m} / \mathrm{z} 703, \mathrm{~m} / \mathrm{z} 733$ and $\mathrm{m} / \mathrm{z} 792$, correspond to di-RLs $\mathrm{Rha}_{2}-\mathrm{C}_{8}-\mathrm{C}_{10: 1} / \mathrm{Rha}_{2}-\mathrm{C}_{8: 1}-\mathrm{C}_{10} / \mathrm{Rha}_{2}-$
$\mathrm{C}_{8: 1}-\mathrm{C}_{10} / \mathrm{Rha}_{2}-\mathrm{C}_{10: 1}-\mathrm{C}_{8}, \mathrm{Rha}_{2}-\mathrm{C}_{12}-\mathrm{C}_{12: 2} / \mathrm{Rha}_{2}-\mathrm{C}_{12: 2}-\mathrm{C}_{12}$, $\mathrm{Rha}_{2}-\mathrm{C}_{12}-\mathrm{C}_{14: 1} / \mathrm{Rha}_{2}-\mathrm{C}_{14: 1}-\mathrm{C}_{12} / \mathrm{Rha}_{2}-\mathrm{C}_{14}-\mathrm{C}_{12: 1} / \mathrm{Rha}_{2}-$ $\mathrm{C}_{12: 1}-\mathrm{C}_{14}$, and $\mathrm{Rha}_{2}-\mathrm{C}_{16}-\mathrm{C}_{14} / \mathrm{Rha}_{2}-\mathrm{C}_{14}-\mathrm{C}_{16}$ that were the most predominant ones. Major ions at $\mathrm{m} / \mathrm{z} 471$ and $\mathrm{m} / \mathrm{z}$ 553 are attributed to the $[\mathrm{M}+\mathrm{Na}]+$ adduct ions for the two major mono-RLs, Rha- $\mathrm{C}_{8}-\mathrm{C}_{8}$ and Rha- $\mathrm{C}_{10}-\mathrm{C}_{12: 1}$ / Rha- $C_{10: 1}-C_{12}$, respectively and ions at $\mathrm{m} / \mathrm{z} 645, \mathrm{~m} / \mathrm{z}$ 671 , and $\mathrm{m} / \mathrm{z} 673$ are attributed to the $[\mathrm{M}+\mathrm{Na}]^{+}$adduct ions for the three major di-RLs, $R_{2} a_{2}-C_{10}-C_{8} / R_{2} a_{2}-C_{8}-$ $\mathrm{C}_{10}, \mathrm{Rha}_{2}-\mathrm{C}_{10}-\mathrm{C}_{10: 1} / \mathrm{Rha}_{2}-\mathrm{C}_{10: 1}-\mathrm{C}_{10}$ and $\mathrm{Rha}_{2}-\mathrm{C}_{10}-\mathrm{C}_{10}$, respectively. Other characteristic ions in mass spectrum appeared at m/z 661 and m/z 689, which corresponds to the molecular $[\mathrm{M}+\mathrm{K}]^{+}$potassium adduct ions of diRLs, Rha $2-\mathrm{C}_{10}-\mathrm{C}_{8} / \mathrm{Rha}_{2}-\mathrm{C}_{8}-\mathrm{C}_{10}$ and $\mathrm{Rha}_{2}-\mathrm{C}_{10}-\mathrm{C}_{10}$, respectively. The molecular $\left[\mathrm{M}-\mathrm{H}+\mathrm{Na}_{2}\right]^{+}$di-sodium adduct ions at $\mathrm{m} / \mathrm{z} 667$ and 695 were also observed for these RLs but in much lower abundance. Moreover, major $\left[\mathrm{M}-\mathrm{H}+\mathrm{Na}_{2}\right]^{+}$molecular ion at $\mathrm{m} / \mathrm{z} 747$ is assigned as $\mathrm{Rha}_{2}-\mathrm{C}_{12}-\mathrm{C}_{12: 2} / \mathrm{Rha}_{2}-\mathrm{C}_{12: 2}-\mathrm{C}_{12}$. Additionally, the [M $+\mathrm{Na}+14]+$ ions at $\mathrm{m} / \mathrm{z} 517$ and at $\mathrm{m} / \mathrm{z} 663$ are due to the methyl esters of mono-RLs with some unsaturated fatty acids $\left[\right.$ Rha- $\left.\left(\mathrm{C}_{10}-\mathrm{C}_{10: 1}\right)\right] /\left[\right.$ Rha- $\left.\left(\mathrm{C}_{10: 1}-\mathrm{C}_{10}\right)\right]$ and di-RLs $\mathrm{Rha}_{2}-\mathrm{C}_{10}-\mathrm{C}_{10: 1} / \mathrm{Rha}_{2}-\mathrm{C}_{10: 1}-\mathrm{C}_{10}$, respectively. Ions assignments are in accordance with the earlier work (Price et al. 2009).

Similarly to the positive ionization, mono-RLs Rha$\mathrm{C}_{10}-\mathrm{C}_{12} /$ Rha- $\mathrm{C}_{12}-\mathrm{C}_{10}$ (m/z 531), Rha- $\mathrm{C}_{10}-\mathrm{C}_{10}$ (m/z 503), Rha- $\mathrm{C}_{8}-\mathrm{C}_{10} /$ Rha- $\mathrm{C}_{8}-\mathrm{C}_{10}(\mathrm{~m} / \mathrm{z} 475)$ and di-RLs $\mathrm{Rha}_{2}-\mathrm{C}_{10^{-}}$ $\mathrm{C}_{12} / \mathrm{Rha}_{2}-\mathrm{C}_{12}-\mathrm{C}_{10}\left(\mathrm{~m} / \mathrm{z}\right.$ 677), $\mathrm{Rha}_{2}-\mathrm{C}_{12}-\mathrm{C}_{12}$ (m/z 705), and $\mathrm{Rha}_{2}-\mathrm{C}_{10}-\mathrm{C}_{10}(\mathrm{~m} / \mathrm{z}$ 649), have been revealed as the main components in the RLs mixture by negative ESI (Table 2). Also, four components with unsaturated fatty acids were found among RLs homologues, which were detected as the anions of $\mathrm{m} / \mathrm{z} 529,647,675$ and 703. These correspond to the de-protonated molecules of RLs, Rha- $\mathrm{C}_{10}-\mathrm{C}_{12: 1} /$ Rha $-\mathrm{C}_{10: 1}-\mathrm{C}_{12}, \mathrm{Rha}_{2}-\mathrm{C}_{10}-\mathrm{C}_{10: 1} / \mathrm{Rha}_{2}-$ $\mathrm{C}_{10: 1}-\mathrm{C}_{10} / \mathrm{Rha}_{2}-\mathrm{C}_{8}-\mathrm{C}_{12: 1} / \mathrm{Rha}_{2}-\mathrm{C}_{8: 1}-\mathrm{C}_{12}, \mathrm{Rha}_{2}-\mathrm{C}_{10}-\mathrm{C}_{12: 1} /$ $\mathrm{Rha}_{2}-\left(\mathrm{C}_{10: 1}-\mathrm{C}_{12} / \mathrm{Rha}_{2}-\mathrm{C}_{12: 1}-\mathrm{C}_{10} / \mathrm{Rha}_{2}-\mathrm{C}_{12}-\mathrm{C}_{10: 1}\right.$ and $\mathrm{Rha}_{2}-$ $\mathrm{C}_{12}-\mathrm{C}_{12: 1} / \mathrm{Rha}_{2}-\mathrm{C}_{12: 1}-\mathrm{C}_{12}$, respectively. Furthermore, some fragments in the mass range 163 - 503 mass arising from the carbohydrate moieties were also evident in the mass spectra, appearing as de-protonated species. Most of the ions above $\mathrm{m} / \mathrm{z} 447$ are RLs pseudo-molecular $[\mathrm{M}-\mathrm{H}]$ - ions and the most ions between $\mathrm{m} / \mathrm{z} 163$ and 503 are fragment ions produced by cleavage (Déziel et al. 1999). The characteristic ion in mass spectrum appeared at $\mathrm{m} / \mathrm{z} 311$, corresponds to the rupture of the link in the rhamnose-alkylic chain of di-RLs. The MS spectrum reveals also a key fragment ion at $\mathrm{m} / \mathrm{z} 293$, which comes from a loss of water molecule. Characteristic ion at $\mathrm{m} / \mathrm{z} 339$ corresponding to removal of an entire rhamnose unit $(\mathrm{m} / \mathrm{z} 163)$ while $\mathrm{m} / \mathrm{z} 333$ indicating removal of a $C_{10}$ fatty acid chain from a mono- $R L$ Rha$\mathrm{C}_{20}(\mathrm{~m} / \mathrm{z} 503)$ were also present. These results clearly 
Table 2 Identification and Characterization of major Rhamnolipids compounds using LC-ESI-MS (Both in negative and positive mode)

\begin{tabular}{|c|c|c|c|c|c|}
\hline Substance & $\begin{array}{l}{[\mathrm{M}+\mathrm{H}]^{+} m /} \\
Z\end{array}$ & $\begin{array}{l}{[\mathrm{M}+\mathrm{Na}]^{+}} \\
m / z\end{array}$ & $\begin{array}{l}{[\mathrm{M}+\mathrm{K}]^{+} m /} \\
z\end{array}$ & $\begin{array}{l}{\left[\mathrm{M}-\mathrm{H}+\mathrm{Na}_{2}\right]^{+}} \\
m / z\end{array}$ & $\begin{array}{l}{[\mathrm{M}-\mathrm{H}]^{-} \mathrm{m} /} \\
z\end{array}$ \\
\hline \multicolumn{6}{|c|}{ Mono-rhamno-mono-lipidic congeners } \\
\hline$\left[\right.$ Rha- $\left.C_{8: 2}\right]$ & 303 & & 341 & & 301 \\
\hline$\left[\right.$ Rha- $\left.C_{8: 1}\right]$ & 305 & & & & \\
\hline$\left[\right.$ Rha- $\left.C_{10: 2}\right]$ & 331 & & & & \\
\hline$\left[\right.$ Rha- $\left.C_{10: 1}\right]$ & 333 & & & & 331 \\
\hline$\left[\right.$ Rha- $\left.C_{10}\right]$ & 335 & & & & \\
\hline$\left[\right.$ Rha- $\left.C_{12: 2}\right]$ & 359 & 381 & & & \\
\hline Octyl phathalate & & 413 & & & \\
\hline \multicolumn{6}{|c|}{ Mono-rhamno-di-lipidic congeners } \\
\hline$\left[\right.$ Rha- $\left.\left(\mathrm{C}_{8}-\mathrm{C}_{8: 1}\right)\right]$ or $\left[\right.$ Rha- $\left.\left(\mathrm{C}_{8: 1}-\mathrm{C}_{8}\right)\right]$ & 447 & & 485 & 491 & 445 \\
\hline$\left[\right.$ Rha- $\left.\left(\mathrm{C}_{8}-\mathrm{C}_{8}\right)\right]$ & 449 & 471 & 487 & 493 & 447 \\
\hline$\left[\right.$ Rha- $\left.\left(C_{10}-C_{8}\right)\right]$ or $\left[\right.$ Rha- $\left.\left(C_{8}-C_{10}\right)\right]$ & 477 & 499 & 515 & 521 & 475 \\
\hline$\left[\right.$ Rha- $\left.\left(C_{8}-C_{10: 1}\right)\right]$ or $\left[\right.$ Rha- $\left.-\left(C_{8: 1}-C_{10}\right)\right]$ & 475 & & & & 473 \\
\hline$\left[\right.$ Rha- $\left.\left(C_{10}-C_{10: 1}\right)\right]$ or $\left[\right.$ Rha- $\left.\left(C_{10: 1}-C_{10}\right)\right]$ & 503 & 525 & 541 & 547 & 501 \\
\hline$\left[\right.$ Rha- $\left.\left(C_{10}-C_{10}\right)\right]$ & 505 & & 543 & & 503 \\
\hline [Rha- $\left.\left(\mathrm{C}_{10}-\mathrm{C}_{10: 1}\right)-\mathrm{CH}_{3}\right]$ or $\left[\mathrm{Rha}-\left(\mathrm{C}_{10: 1}-\mathrm{C}_{10}\right)-\mathrm{CH}_{3}\right]$ & 517 & & & & \\
\hline$\left[\right.$ Rha- $\left.-\left(C_{10}-C_{12: 1}\right)\right]$ or $\left[\right.$ Rha- $\left.\left(C_{10: 1}-C_{12}\right)\right]$ & 531 & 553 & 569 & 575 & 529 \\
\hline$\left[\right.$ Rha- $\left.\left(C_{10}-C_{12}\right)\right]$ or $\left[\right.$ Rha- $\left.\left(C_{12}-C_{10}\right)\right]$ & 533 & 555 & 571 & 577 & 531 \\
\hline$\left[\right.$ Rha- $\left.\left(C_{12}-C_{14: 1}\right)\right]$ or $\left[\right.$ Rha- $\left.\left(C_{14}-C_{12: 1}\right)\right]$ & 587 & & 625 & 631 & 585 \\
\hline$\left[\right.$ Rha- $\left.\left(C_{14}-C_{14}\right)\right]$ & 617 & & & 661 & \\
\hline$\left[\right.$ Rha- $\left.\left(C_{14}-C_{14: 1}\right)\right]$ or $\left[\right.$ Rha- $\left.\left(C_{14: 1}-C_{14}\right)\right]$ & 615 & & & & 613 \\
\hline$\left[\right.$ Rha- $\left.\left(C_{14}-C_{16}\right)\right]$ or $\left[\right.$ Rha- $\left.\left(C_{16}-C_{14}\right)\right]$ & 645 & & & & 643 \\
\hline$\left[\right.$ Rha- $\left.\left(C_{14}-C_{16: 1}\right)\right]$ or $\left[\right.$ Rha- $\left.\left(C_{14}-C_{16: 1}\right)\right]$ & 643 & & & & 641 \\
\hline$\left[\operatorname{Rha}-\left(\mathrm{C}_{16}-\mathrm{C}_{16}\right)\right]$ & 673 & & & & 671 \\
\hline \multicolumn{6}{|c|}{ Di-rhamno-mono-lipidic congeners } \\
\hline$\left[\right.$ Rha-Rha- $\left.\left.C_{8}\right)\right]$ & 453 & & & & 451 \\
\hline$\left[\right.$ Rha-Rha- $\left.\left.C_{10: 1}\right)\right]$ & 479 & & & & 477 \\
\hline$\left[\right.$ Rha-Rha- $\left.\left.C_{10}\right)\right]$ & 481 & & & & 479 \\
\hline$\left[\right.$ Rha-Rha- $\left.\left.C_{12: 1}\right)\right]$ & 507 & & & & 505 \\
\hline$\left[\right.$ Rha-Rha- $\left.\left.C_{12}\right)\right]$ & 509 & & & & 507 \\
\hline \multicolumn{6}{|c|}{ Di-rhamno-di-lipidic congeners } \\
\hline$\left[\right.$ Rha-Rha- $\left.\left(\mathrm{C}_{8}-\mathrm{C}_{8}\right)\right]$ & 595 & 617 & 633 & & 593 \\
\hline $\begin{array}{l}\left.\text { [Rha-Rha- }\left(C_{8}-C_{10: 1}\right)\right] \text { or }\left[\text { Rha-Rha- }\left(C_{8: 1}{ }^{-} C_{10}\right)\right]\left[\text { Rha-Rha- }\left(C_{10}-C_{8: 1}\right)\right] \text { or }\left[\text { Rha-Rha- }\left(C_{10: 1^{-}}\right.\right. \\
\left.\left.C_{8}\right)\right]\end{array}$ & 621 & & 659 & 665 & 619 \\
\hline$\left[\right.$ Rha-Rha- $\left.\left(\mathrm{C}_{10}-\mathrm{C}_{8}\right)\right]$ or $\left[\right.$ Rha-Rha- $\left.\left(\mathrm{C}_{8}-\mathrm{C}_{10}\right)\right]$ & 623 & 645 & 661 & 667 & 621 \\
\hline$\left[\right.$ Rha-Rha- $\left.\left(C_{10}-C_{10}\right)\right]$ & 651 & 673 & 689 & 695 & 649 \\
\hline $\begin{array}{l}\left.\text { [Rha-Rha- }\left(C_{10}-C_{10: 1}\right)\right] \text { or }\left[\text { Rha-Rha- }\left(C_{10: 1}-C_{10}\right)\right] \\
{\left[\text { Rha-Rha- }\left(C_{8}-C_{12: 1}\right)\right] \text { or }\left[\text { Rha-Rha- }\left(C_{8: 1}-C_{12}\right)\right]}\end{array}$ & 649 & 671 & 687 & 693 & 647 \\
\hline [Rha-Rha- $\left.\left(\mathrm{C}_{10}-\mathrm{C}_{10: 1}\right)-\mathrm{CH}_{3}\right]$ or [Rha-Rha- $\left.\left(\mathrm{C}_{10: 1}-\mathrm{C}_{10}\right)-\mathrm{CH}_{3}\right]$ & 663 & & & & \\
\hline $\begin{array}{l}\left.\text { [Rha-Rha- }\left(C_{10}-C_{12: 1}\right)\right] \text { or }\left[\text { Rha-Rha- }\left(C_{10: 1}-C_{12}\right)\right]\left[\text { Rha-Rha- }\left(C_{12: 1}-C_{10}\right)\right] \text { or [Rha-Rha- } \\
\left.\left(C_{12}-C_{10: 1}\right)\right]\end{array}$ & 677 & 699 & 715 & 721 & 675 \\
\hline$\left[\right.$ Rha-Rha- $\left.\left(\mathrm{C}_{10}-\mathrm{C}_{12}\right)\right]$ or $\left[\right.$ Rha-Rha- $\left.\left(\mathrm{C}_{12}-\mathrm{C}_{10}\right)\right]$ & 679 & 701 & 717 & 723 & 677 \\
\hline [Rha-Rha- $\left.\left(C_{12}-C_{12: 1}\right)\right]$ or [Rha-Rha- $\left.\left(C_{12: 1}-C_{12}\right)\right]$ & 705 & 727 & 743 & 749 & 703 \\
\hline$\left[\right.$ Rha-Rha- $\left.\left(C_{12}-C_{12: 2}\right)\right]$ or [Rha-Rha- $\left.\left(C_{12: 2}-C_{12}\right)\right]$ & 703 & 725 & 741 & 747 & 701 \\
\hline$\left[\right.$ Rha-Rha- $\left.\left(C_{12}-C_{12}\right)\right]$ & 707 & 729 & & 751 & 705 \\
\hline $\begin{array}{l}\left.\left.\left.\text { [Rha-Rha- }\left(\mathrm{C}_{12}-\mathrm{C}_{14: 1}\right)\right] \text { or [Rha-Rha- }\left(\mathrm{C}_{14: 1}-\mathrm{C}_{12}\right)\right] \text { [Rha-Rha- }\left(\mathrm{C}_{14}-\mathrm{C}_{12: 1}\right)\right] \text { or [Rha-Rha- } \\
\left.\left(\mathrm{C}_{12: 1}-\mathrm{C}_{14}\right)\right]\end{array}$ & 733 & & & 777 & 731 \\
\hline$\left[\right.$ Rha-Rha- $\left.\left(C_{14}-C_{14: 1}\right)\right]$ or $\left[\right.$ Rha-Rha- $\left.\left(C_{14: 1}-C_{14}\right)\right]$ & 762 & 784 & & 806 & 760 \\
\hline [Rha-Rha- $\left.\left(\mathrm{C}_{16}-\mathrm{C}_{14}\right)\right]$ or $\left[\right.$ Rha-Rha- $\left.\left(\mathrm{C}_{14}-\mathrm{C}_{16}\right)\right]$ & 792 & 814 & & & 790 \\
\hline
\end{tabular}

Data shown in bold represent major components of the corresponding Rhamnolipid mixture 
show that $\mathrm{Rha}-\mathrm{C}_{10}-\mathrm{C}_{10} \mathrm{RL}$ homolog is the predominant one compared to a mixture of Rha- $\mathrm{C}_{8}-\mathrm{C}_{12}$ and $\mathrm{Rha}-\mathrm{C}_{12}$ $\mathrm{C}_{8}$ (Camilios Neto et al. 2009). Major ions at $\mathrm{m} / \mathrm{z} 283$, $\mathrm{m} / \mathrm{z} 393$ and $\mathrm{m} / \mathrm{z} 421$ are attributed to removal of an entire rhamnose unit from $\mathrm{Rha}-\mathrm{C}_{8}-\mathrm{C}_{8}(\mathrm{~m} / \mathrm{z}$ 163), and an di-rhamnose unit (m/z 309), from RLs with some unsaturated fatty acid, $\mathrm{Rha}_{2}-\mathrm{C}_{12}-\mathrm{C}_{12: 1} / \mathrm{Rha}_{2}-\mathrm{C}_{12: 1}-\mathrm{C}_{12}$ and $\mathrm{Rha}_{2}$ $\mathrm{C}_{12}-\mathrm{C}_{14: 1} / \mathrm{Rha}_{2}-\mathrm{C}_{14: 1}-\mathrm{C}_{12} / \mathrm{Rha}_{2}-\mathrm{C}_{14}-\mathrm{C}_{12: 1} / \mathrm{Rha}_{2}-\mathrm{C}_{12: 1}-\mathrm{C}_{14}$, respectively. The observed 28 mass unit difference between $\mathrm{m} / \mathrm{z} 393$ and $\mathrm{m} / \mathrm{z} 421$ ions corresponds to the mass difference between the $C_{12}$ and $C_{14}$ acyl moiety. Characteristic ions of rhamnose and di-rhamnose moiety were also appeared at m/z 163 and 309 with low relative abundance. Another characteristic ion at $\mathrm{m} / \mathrm{z} 247$ that might potentially have been produced by the fragmentation of $\mathrm{Rha}_{2}-\mathrm{C}_{10}-\mathrm{C}_{10}$ (Camilios-Neto et al. 2010,; ZgolaGrzéskowiak and Kaczorek 2011) and $\mathrm{Rha}_{2}-\mathrm{C}_{10}-\mathrm{C}_{12}$ and $\mathrm{Rha}_{2}-\mathrm{C}_{10}-\mathrm{C}_{12: 1}$ (Monteiro et al. 2007,) RLs was also present. The available information provided by mass spectrometry was not sufficient to precisely elucidate the structure of this ion. The characterization of negative ESI MS spectra is consistent with earlier studies (CamiliosNeto et al. 2010,; Monteiro et al. 2007). By comparing the two ionization modes, it appears that both were sensitive and suitable for the majority of the analyzed compounds. Each mode provided complementary information that enabled the full and unambiguous identification of the RLs homologues.

\section{Discussion}

T. thermophilus was demonstrated to be capable to produce simultaneously two biotechnologically important bio-products; biodegradable biopolymers PHAs and RLs-type biosurfactants by utilizing either glucose or sodium gluconate as sole carbon source, although the ability to produce them, and especially RLs, is in fact restricted to a limited number of bacterial species (Abdel-Mawgoud et al. 2010). One of the long-term interests of the scientists is to produce RLs in strains other than the opportunistic known pathogen $P$. aeruginosa (Chwalek et al. 2006) due to the wide field of their applications. This paper contributes to this goal taken into account the advantages of $T$. thermophilus HB8 due to the exceptionality of the non-pathogenic and thermophilic nature of this strain, and its capability of naturally producing these metabolites. Apart from the advantages resulting from the thermophilicity of the microorganism that reflects positively on the solubility of substrates and the reduced likelihood of contamination should be taken into account the requirement of high temperature of $75^{\circ}$ $\mathrm{C}$ and consequently the high cost of energy for bacterial growth, and production of both bio-products. A good compensation for overcoming this problem will be the use of inexpensive wastes substrates.
The usage of $T$. thermophilus for their production in low cost seems highly promising due to the high solubility of suitable carbon sources located in wastes, especially of water-immiscible substrates, where RLs production was high. The consumption of gluconate as sole carbon source by $T$. thermophilus resulted in higher production of both metabolites than that when glucose was used. Among the various initial $\left[\mathrm{PO}_{4}{ }^{3-}\right]$ tested, the medium containing initially $25 \mathrm{mM}$ of $\left[\mathrm{PO}_{4}{ }^{3-}\right]$ resulted in the higher polymer production after $72 \mathrm{~h}$ of cultivation (Table 1), consistent with the report that the initial $\left[\mathrm{PO}_{4}{ }^{3-}\right]$ in the culture medium influences both the cell density and the PHAs production (Lee et al. 2000). The recovery of PHAs requires the disruption of valuable biocatalysts of bacterial cells, while the production of secreted materials, such as RLs, in combination with PHAs production is expected to enhance the availability of biocatalysts because the cells can be used as "microbial cell factories" for the production of the exo-products before the eventual disruption to recover PHAs.

The investigation of the combine effect of both the cultivation time and the initial $\left[\mathrm{PO}_{4}{ }^{3-}\right]$ on biomass, and on simultaneous PHAs and RLs production was evaluated from contour plots (Figure 3). As it was revealed, biomass was increased by increasing both initial $\left[\mathrm{PO}_{4}{ }^{3-}\right]$ and cultivation time in the experimental ranges tested. However, a further increase of the initial $\left[\mathrm{PO}_{4}{ }^{3-}\right]$ and cultivation time would lead the contours to convergence at a concrete point (Figure 3a). Moreover, PHAs production was increasing during cultivation time but there would not be further rise in PHAs production obtained by increasing $\left[\mathrm{PO}_{4}{ }^{3-}\right]$ above a crucial concentration, i.e. above $30 \mathrm{mM}$ (Figure 3b), as it can be deduced by the convergence of the curve toward the center point of initial phosphate concentration. In contrast, the increase of the initial $\left[\mathrm{PO}_{4}{ }^{3-}\right]$ had a negative effect on RLs production, but the biosurfactant concentration increased during cultivation time (Figure 3c). These results revealed that PHAs synthesis occurred only during active cell growth, while substantial RLs production began early but is completed at the onset of the stationary phase. This strategy might be useful as the beginning to optimize other parameters affecting these processes such as nitrogen, carbon sources etc.

PHAs synthesized in both carbon sources are copolymers with a very similar composition of monomers possessing carbon chain lengths ranging from 6-12 carbon atoms. Since PHAs and RLs syntheses have a close metabolic relation, since (R)-3-hydroxyfatty acids are used as common precursors in both pathways, it has been proposed that both PHAs and RLs biosynthesis pathways may compete for (R)-3-hydroxyfatty acid ACP (Rehm et al. 2001,; Soberón-Chávez et al. 2005). However, there is still no clear evidence for this probable 
competitive relation. A regulatory switch of the flow of beta-hydroxyalkanoic acids from PHAs polymerization to RLs synthesis is clearly indicated to occur when the culture reaches the stationary phase.

Recently, a proposed distributional pathways of (R)-3hydroxyacyl groups for the synthesis of PHAs, HAAs ((R)-3-((R)-3-hydroxyalkanoyloxy) alkanoic acids), mono-RLs and di-RLs in Pseudomonas aeruginosa grown on medium-chain-length fatty acids was published. It was suggested that during the exponential cell growth, cells excessively produced free acids $3 \mathrm{HAs}$ (such as $3 \mathrm{HO}, 3 \mathrm{HD}$, etc.), which are secreted into medium and retake-up later for RLs syntheses (Choi et al. 2011). An interrelationship between PHAs and RLs synthesis was found that in rhamnolipid-negative mutants, more (R)-3-hydroxyfatty acid precursors were fluxed toward PHA synthesis. However, the production of rhamnolipid in $P$. aeruginosa seemed to be very tightly regulated at the transcriptional level by the quorum-sensing response and by environmental conditions. Finally, investigation of metabolic pathway for PHAs and RLs synthesis using octanoic- $1-{ }^{13} \mathrm{C}$ acid suggested that the fatty acid substrate was converted to PHAs and the acyl groups in the RLs with a minimum number of rearrangements (Choi et al. 2011).

Concerning T. thermophilus HB8, there is no other information apart of our works for the biosynthetic pathway of PHAs and RLs neither for the corresponding genes in the genome, except that only a rhamnosyltransferase (YP-144151; TTHA00885) was found, exhibiting a calculated molecular weight of 32,783 , and consisting of 290 amino acids (Pantazaki et al. 2010,). Recently it was also demonstrated the potential production of RLs by fatty acids by cultivating this bacterium in the presence of sunflower seed oil or oleic acid as carbon sources (Pantazaki et al. 2010) or by sugars such as glucose and its derivative sodium gluconate in this work. Taking into account that $T$. thermophilus produce mcl-PHAs, in which 3-hydroxydecanoate constituted the major constituent when grown in the presence of gluconate, and since 3-hydroxydecanoate can be formed via $\beta$-oxidation or via fatty acid de novo biosynthesis, we can suggest that both biosynthesis pathways, might be involved in RLs biosynthesis in this bacterium dependent on the carbon source used (Pantazaki et al. 2010,). The $\beta$-oxidation leads to the desired $\mathrm{R}$-configurated hydroxy acid and the de novo biosynthesis at first to the S-configurated compound (additional biochemical reactions are necessary to give also in this case the accurate configuration of the polymer precursor). These results confirmed that the type of RLs produced depends on multiple conditions, including the bacterial strain and the carbon source used as previously reported (Mulligan and Gibbs 1993,; Robert et al. 1989).
The extracted mixture of RLs produced in the presence of sodium gluconate was subjected to identification and characterization using LC-(ESI)-MS. LC-MS analyses revealed that both mono- and di-RL moieties as well as di-rhamno-mono-lipidic congeners were present in the RLs mixture. Additionally, a plethora of diversity of mono- and di-RLs as well, was identified differing in the length of the lipidic chain, which additionally found to be saturated or unsaturated in some cases (Table 2). The combination of negative and positive ESI modes has been shown to be powerful tools in the characterization of RLs homologues. The wild type strain of T. thermophilus HB8 make all RL biosynthetic intermediates under the described growth conditions. This approach could be further applied successfully for the structural elucidation of biosurfactants producing from the substrate mixture of others sources of carbon.

The detailed and extensive RLs characterization of this work demonstrated that a plethora of diversity of monoand di-RLs were identified differing in the length of the lipidic chain, which additionally found to be saturated or unsaturated in some cases. However, the diversity of $\beta$-hydroxyalkanoic acids that are participated in the PHAs synthesized by $T$. thermophilus was not as wide as this of $\beta$-hydroxyalkanoic acids that was involved in RLs synthesis and not at all so similar. Moreover, it is known that the composition of PHAs depends on substrate specificity of the PHA polymerases which uses (R)-3-hydroxyalkanoyl-CoA as substrates (Lee et al. 2004). This observation directs to the bold suggestion that RLs production might constitutes a mechanism of exhaustion of the accumulated $\beta$-hydroxyalkanoic acids unused "wastes" by-products from the cells to the exterior medium, since in this bacterium anyhow the RLs production began early but is completed at the onset of the stationary phase.

Secreted RLs are recorded as virulence factors of the producing microorganisms (Abdel-Mawgoud et al. 2010,). Among the RLs constituents, there is evidence that attributes the implication of the lipidic chain to triggering of some biological effects such as cytotoxicity or heamolytic activity. RLs possessing the same glycoside chain can also have a different influence when the aglycone is only slightly modified. The hydrophobic aglycone backbone could probably intercalate into the hydrophobic membrane bi-layer, while the glycoside chain could interact with the polar group (Chwalek et al. 2006).

Surface-active compounds commonly used by industry are chemically synthesized, and their replacement with bio-surfactants could provide advantages. Bio-surfactants compared to chemically synthesized surfactants have been receiving increasing attention as a result of their unique properties, mild production conditions, lower 
environmental toxicity, and higher biodegradability (Mulligan 2005,; Rosenberg and Ron 1999,). However, the use of bio-surfactants has been limited currently due to their relatively high production cost since the main factor limiting commercialization of bio-surfactants is associated with non-economical large scale production. To surmount this obstacle and to compete with synthetic surfactants, inexpensive substrates and effective microorganisms must be developed for bio-surfactant production. Agro-industrial wastes are considered as the most promising substrates for low-cost bio-surfactant production and can alleviate many processing industrial waste management problems. This would lead to the greater possibility for economical biosurfactant production and reduced pollution caused by those wastes (Maneerat 2005). Aforementioned, many microorganisms, especially Pseudomonads, were reported use various low-cost renewable resources as potential carbon sources, but they cannot produce bio-surfactants or only have very low yield. Screening of high RLs-producing microorganisms from the natural environment is a good choice, for RLs production.

These efficient cultivation processes and their mechanisms as they pertain to the simultaneous production of PHAs and RLs encourage us to the use of a range of inexpensive carbon sources containing sugars or fatty acids. The establishment of lab-scale bioreactor experiments that will design in a future project that will include more factors affecting both biosynthetic processes might significantly increase the production of both bio-products, PHAs and RLs.

\section{Acknowledgements}

The authors would like to thank the Mass Spectrometry Unit of the University of loannina for the providing access to LC-MS facilities.

\section{Author details}

'Laboratory of Biochemistry, Dept. of Chemistry, Aristotle University of Thessaloniki, 54124 Thessaloniki, Greece ${ }^{2}$ Environmental Pollution Control Laboratory, Dept. of Chemistry, Aristotle University of Thessaloniki, 54124 Thessaloniki, Greece

\section{Competing interests}

The author declares that they have no competing interests.

Received: 3 July 2011 Accepted: 13 July 2011 Published: 13 July 2011

\section{References}

Abdel-Mawgoud AM, Lépine F, Déziel E (2010) Rhamnolipids: diversity of structures, microbial origins and roles. Appl Microbiol Biotechnol 86:1323-1336. doi:10.1007/s00253-010-2498-2.

Amara AA, Rehm BH (2003) Replacement of the catalytic nucleophile cysteine296 by serine in class II polyhydroxyalkanoate synthase from Pseudomonas aeruginosa-mediated synthesis of a new polyester: identification of catalytic residues. Biochem J 374:413-421. doi:10.1042/BJ20030431.

Anderson AJ, Dawes EA (1990) Occurrence, metabolism, metabolic role, and industrial uses of bacterial polyhydroxyalkanoates. Microbiol Rev 54:450-472

Braunegg G, Sonnleitner B, Lafferty RM (1978) A rapid method for the determination of poly- $\beta$-hydroxybutyric acid in microbial biomass. Eur J Appl Microbiol Biotechnol 6:29-37. doi:10.1007/BF00500854.
Camilios-Neto D, Bugay C, de Santana-Filho AP, Joslin T, de Souza LM, Sassaki GL, Mitchell DA, Krieger N (2010) Production of rhamnolipids in solid-state cultivation using a mixture of sugarcane bagasse and corn bran supplemented with glycerol and soybean oil. Appl Microbiol Biotechnol 89:1395-1403

Camilios Neto D, Meira JA, Tiburtius E, Zamora PP, Bugay C, Mitchell DA, Krieger N (2009) Production of rhamnolipids in solid-state cultivation: Characterization, downstream processing and application in the cleaning of contaminated soils. Biotechnol J 4:748-755. doi:10.1002/biot.200800325.

Campos-Garcia J, Caro AD, Najera R, Miller-Maier RM, Al-Tahhan RA, SoberónChávez G (1998) The Pseudomonas aeruginosa rhlG gene encodes an $\mathrm{NADPH}$-dependent beta-ketoacyl reductase which is specifically involved in rhamnolipid synthesis. J Bacteriol 180:4442-4451

Chakrabarty AM (1985) Genetically manipulated microorganisms and their products in the oil service industries. Trends Biotechnol 3:32-38. doi:10.1016/ 0167-7799(85)90056-3.

Choi MH, Xu J, Gutierrez M, Yoo T, Cho YH, Yoon SC (2011) Metabolic relationship between polyhydroxyalkanoic acid and rhamnolipid synthesis in Pseudomonas aeruginosa: comparative ${ }^{13} \mathrm{C}$ NMR analysis of the products in wild-type and mutants. J Biotechnol 151:30-42. doi:10.1016/j. jbiotec.2010.10.072.

Chwalek M, Lalun N, Bobichon H, Ple K, Voutquenne-Nazabadioko L (2006) Structure-activity relationships of some hederagenin diglycosides: haemolysis, cytotoxicity and apoptosis induction. Biochim Biophys Acta 1760:1418-1427

Dawes EA (1986) Microbial energetics. Blakie \& Son Limited, Bishopbriggs, Glasgow

Déziel E, Lépine F, Dennie D, Boismenu D, Mamer OA, Villemur R (1999) Liquid chromatography/mass spectrometry analysis of mixtures of rhamnolipids produced by Pseudomonas aeruginosa strain 57RP grown on mannitol or naphthalene. Biochim Biophys Acta 1440:244-252

Déziel E, Lépine F, Milot S, Villemur R (2003) rhlA is required for the production of a novel biosurfactant promoting swarming motility in Pseudomonas aeruginosa: 3-(3-hydroxyalkanoyloxy)alkanoic acids (HAAs), the precursors of rhamnolipids. Microbiology 149:2005-2013. doi:10.1099/mic.0.26154-0.

Déziel E, Paquette G, Villemur R, Lépine F, Bisaillon J (1996) Biosurfactant production by a soil pseudomonas strain growing on polycyclic aromatic hydrocarbons. Appl Environ Microbiol 62:1908-1912

Fiske CH, SubbaRow Y (1925) The colorimetric determination of phosphorus. J Biol Chem 66:375-400

Füchtenbusch B, Wullbrandt D, Steinbüchel A (2000) Production of polyhydroxyalkanoic acids by Ralstonia eutropha and Pseudomonas oleovorans from an oil remaining from biotechnological rhamnose production. Appl Microbiol Biotechnol 53:167-172. doi:10.1007/ s002530050004.

Griebel R, Smith Z, Merrick JM (1968) Metabolism of poly-beta-hydroxybutyrate. I. Purification, composition, and properties of native poly-beta-hydroxybutyrate granules from Bacillus megaterium. Biochemistry 7:3676-3681. doi:10.1021/ bi00850a047.

Guerra-Santos L, Kappeli O, Fiechter A (1986) Dependence of Pseudomonas aeruginosa continuous culture biosurfactant production on nutritional and environmental factors. Appl Microbiol Biotechnol 24:443-448

Haba E, Pinazo A, Jauregui O, Espuny MJ, Infante MR, Manresa A (2003) Physicochemical characterization and antimicrobial properties of rhamnolipids produced by Pseudomonas aeruginosa 47T2 NCBIM 40044. Biotechnol Bioeng 81:316-322. doi:10.1002/bit.10474.

Hauser G, Karnovsky ML (1954) Studies on the production of glycolipide by Pseudomonas aeruginosa. J Bacteriol 68:645-654. doi:10.1002/ path. 1700680242 .

Hauser G, Karnovsky ML (1958) Studies on the biosynthesis of L-rhammose. J Biol Chem 233:287-291

Hori K, Marsudi S, Unno H (2002) Simultaneous production of polyhydroxyalkanoates and rhamnolipids by Pseudomonas aeruginosa. Biotechnol Bioeng 78:699-707. doi:10.1002/bit.10248.

Huijberts GN, Eggink G, de Waard P, Huisman GW, Witholt B (1992) Pseudomonas putida KT2442 cultivated on glucose accumulates poly(3-hydroxyalkanoates) consisting of saturated and unsaturated monomers. Appl Environ Microbiol 58:536-544

Huisman GW, de Leeuw O, Eggink G, Witholt B (1989) Synthesis of poly-3hydroxyalkanoates is a common feature of fluorescent Pseudomonads. Appl Environ Microbiol 55:1949-1954 
Itoh S, Suzuki T (1972) Effect of rhamnolipids on growth of Pseudomonas aeruginosa mutant deficient in $\mathrm{n}$-paraffinutilizing ability. Agric Biol Chem 36:1233-1235

Koch AK, Kappeli O, Fiechter A, Reiser J (1991) Hydrocarbon assimilation and biosurfactant production in Pseudomonas aeruginosa mutants. J Bacteriol $173: 4212-4219$

Kulaev IS (1985) Some aspects of environmental regulation of microbial phosphorus metabolism. FEMS Syrnp 23:1-25

Lee SY (1996) Bacterial polyhydroxyalkanoates. Biotechnol Bioeng 49:1-14. doi:10.1002/(SICI)1097-0290(19960105)49:13.3.CO;2-1.

Lee SY, Wong HH, Choi J, Lee SH, Lee SC, Han CS (2000) Production of mediumchain-length polyhydroxyalkanoates by high-cell-density cultivation of Pseudomonas putida under phosphorus limitation. Biotechnol Bioeng 68:466-470. doi:10.1002/(SICI)1097-0290(20000520)68:43.0.CO;2-T.

Lee H-J, Rho JK, Noghabi KA, Lee SE, Choi MH, Yoon SC (2004) Channeling of intermediates derived from medium-chain fatty acids and de novosynthesized fatty acids to polyhydroxyalkanoic acid by 2-bromooctanoic acid in Pseudomonas fluorescens BM07. J Microbiol Biotechnol 14:1256-1266

Lotfabad TB, Abassi H, Ahmadkhaniha R, Roostaazad R, Masoomi F, Zahiri HS, Ahmadian G, Vali H, Noghabi KA (2010) Structural characterization of a rhamnolipid-type biosurfactant produced by Pseudomonas aeruginosa MR01: enhancement of di-rhamnolipid proportion using gamma irradiation. Colloids Surf B Biointerfaces 81:397-405. doi:10.1016/j.colsurfb.2010.06.026.

Maier RM, Soberón-Chávez G (2000) Pseudomonas aeruginosa rhamnolipids: biosynthesis and potential applications. Appl Microbiol Biotechnol 54:625-633. doi:10.1007/s002530000443.

Maneerat S (2005) Production of biosurfactants using substrates from renewable resources. Songklanakarin J Sci Technol 27:675-683

Marsudi S, Unno H, Hori K (2008) Palm oil utilization for the simultaneous production of polyhydroxyalkanoates and rhamnolipids by Pseudomonas aeruginosa. Appl Microbiol Biotechnol 78:955-961. doi:10.1007/s00253-0081388-3.

Mata-Sandoval JC, Karns J, Torrents A (1999) High-performance liquid chromatography method for the characterization of rhamnolipid mixtures produced by Pseudomonas aeruginosa UG2 on corn oil. J Chromatogr A 864:211-220. doi:10.1016/S0021-9673(99)00979-6.

Monteiro SA, Sassaki GL, de Souza LM, Meira JA, de Araujo JM, Mitchell DA, Ramos LP, Krieger N (2007) Molecular and structural characterization of the biosurfactant produced by Pseudomonas aeruginosa DAUPE 614. Chem Phys Lipids 147:1-13. doi:10.1016/j.chemphyslip.2007.02.001.

Mulligan CN (2005) Environmental applications for biosurfactants. Environ Pollut 133:183-198. doi:10.1016/j.envpol.2004.06.009.

Mulligan CN, Gibbs BF (1993) Factors influencing the economics of biosurfactants. In: Kosaric N (ed) Biosurfactants, production, properties, applications. New York: Marcel Dekker

Ochsner UA, Reiser J (1995) Autoinducer-mediated regulation of rhamnolipid biosurfactant synthesis in Pseudomonas aeruginosa. Proc Natl Acad Sci USA 92:6424-6428. doi:10.1073/pnas.92.14.6424.

Pantazaki AA, Dimopoulou MI, Simou OM, Pritsa AA (2010) Sunflower seed oil and oleic acid utilization for the production of rhamnolipids by Thermus thermophilus HB8. Appl Microbiol Biotechnol 88:939-951. doi:10.1007/s00253010-2802-1.

Pantazaki AA, loannou AK, Kyriakidis DA (2005) A thermostable beta-ketothiolase of polyhydroxyalkanoates (PHAs) in Thermus thermophilus: purification and biochemical properties. Mol Cell Biochem 269:27-36. doi:10.1007/s11010-0052992-5.

Pantazaki AA, Papaneophytou CP, Pritsa AG, Liakopoulou-Kyriakides M, Kyriakidis D (2009) Production of polyhydroxyalkanoates from whey by Thermus thermophilus HB8. Process Biochem 44:847-853. doi:10.1016/j. procbio.2009.04.002

Pantazaki AA, Tambaka MG, Langlois V, Guerin P, Kyriakidis DA (2003) Polyhydroxyalkanoate (PHA) biosynthesis in Thermus thermophilus: purification and biochemical properties of PHA synthase. Mol Cell Biochem 254:173-183. doi:10.1023/A:1027373100955.

Pearson JP, Pesci EC, Iglewski BH (1997) Roles of Pseudomonas aeruginosa las and rhl quorum-sensing systems in control of elastase and rhamnolipid biosynthesis genes. J Bacteriol 179:5756-5767

Price NP, Ray KI, Vermillion K, Kuo TM (2009) MALDI-TOF mass spectrometry of naturally occurring mixtures of monorhamnolipids and dirhamnolipids. Carbohydr Res 344:204-209. doi:10.1016/..carres.2008.10.013.
Qi Q, Steinbüchel A, Rehm BH (2000) In vitro synthesis of poly(3hydroxydecanoate): purification and enzymatic characterization of type II polyhydroxyalkanoate synthases $\mathrm{PhaC1}$ and PhaC2 from Pseudomonas aeruginosa. Appl Microbiol Biotechnol 54:37-43. doi:10.1007/s002530000357.

Rahim R, Ochsner UA, Olvera C, Graninger M, Messner P, Lam JS, SoberónChávez G (2001) Cloning and functional characterization of the Pseudomonas aeruginosa rhlC gene that encodes rhamnosyltransferase 2, an enzyme responsible for di-rhamnolipid biosynthesis. Mol Microbiol 40:708-718. doi:10.1046/j.1365-2958.2001.02420.x.

Reddy CS, Ghai R, Rashmi Kalia VC (2003) Polyhydroxyalkanoates: an overview. Bioresour Technol 87:137-146. doi:10.1016/S0960-8524(02)00212-2.

Rehm BH (2003) Polyester synthases: natural catalysts for plastics. Biochem J 376:15-33. doi:10.1042/BJ20031254.

Rehm BH, Mitsk A, Steinbüchel A (2001) Role of fatty acid de novo biosynthesis in polyhydroxyalkanoic acid (PHA) and rhamnolipid synthesis by Pseudomonads: establishment of the transacylase (PhaG)-mediated pathway for PHA biosynthesis in Escherichia coli. Appl Environ Microbiol 67:3102-3109. doi:10.1128/AEM.67.7.3102-3109.2001.

Rehm BH, Steinbüchel A (1999) Biochemical and genetic analysis of PHA synthases and other proteins required for PHA synthesis. Int J Biol Macromol 25:3-19. doi:10.1016/50141-8130(99)00010-0.

Ren Q, De Roo G, Kessler B, Witholt B (2000) Recovery of active medium-chainlength-poly-3-hydroxyalkanoate polymerase from inactive inclusion bodies using ion-exchange resin. Biochem J 349:599-604. doi:10.1042/02646021:3490599.

Robert M, Mercade ME, Bosch MP, Parra JL, Espiny MJ, Manresa MA, Guinea J (1989) Effect of the carbon source on biosurfactant production by Pseudomonas aeruginosa 44 T1. Biotechnol Lett 11:871-874. doi:10.1007/ BF01026843.

Rooney AP, Price NP, Ray KJ, Kuo TM (2009) Isolation and characterization of rhamnolipid-producing bacterial strains from a biodiesel facility. FEMS Microbiol Lett 295:82-87. doi:10.1111/j.1574-6968.2009.01581.x.

Rosenberg E, Ron EZ (1999) High- and low-molecular-mass microbial surfactants. Appl Microbiol Biotechnol 52:154-162. doi:10.1007/s002530051502.

Rusendi D, Sheppard JD (1995) Hydrolysis of potato processing waste for the production of poly- $\beta$-hydroxybutyrate. Bioresour Technol 54:191-196. doi:10.1016/0960-8524(95)00124-7.

Schenk T, Schuphan I, Schmidt B (1995) High-performance liquid chromatographic determination of the rhamnolipids produced by Pseudomonas aeruginosa. J Chromatogr A 693:7-13. doi:10.1016/0021-9673 (94)01127-Z.

Sim L, Ward OP, Li ZY (1997) Production and characterization of a biosurfactant isolated from Pseudomonas aeruginosa UW-1. J Ind Microbiol Biotechnol 19:232-238. doi:10.1038/s.j.jm.2900450.

Soberón-Chávez G, Lépine F, Déziel E (2005) Production of rhamnolipids by Pseudomonas aeruginosa. Appl Microbiol Biotechnol 68:718-725. doi:10.1007/ s00253-005-0150-3.

Syldatk C, Lang S, Matulovic U, Wagner F (1985) Production of four interfacial active rhamnolipids from $n$-alkanes or glycerol by resting cells of Pseudomonas species DSM 2874. Z Naturforsch C 40:61-67

Valappil SP, Misra SK, Boccaccini AR, Roy I (2006) Biomedical applications of polyhydroxyalkanoates: an overview of animal testing and in vivo responses. Expert Rev Med Devices 3:853-868. doi:10.1586/17434440.3.6.853.

Wagner F, Bock H, Kretschmer A, Lang S, Syldatk C (1983) Production and chemical characterization of surfactants from Rhodococcus erythropolis and Pseudomonas sp. MUB grown on hydrocarbons. In: Zajic JE, Cooper DG, Jack TR, Kosaric N (eds) Microbial enhanced oil recovery. Tucson, Arizona, p. $55-60$

Zgola-Grzéskowiak A, Kaczorek E (2011) Isolation, preconcentration and determination of rhamnolipids in aqueous samples by dispersive liquid-liquid microextraction and liquid chromatography with tandem mass spectrometry. Talanta 83:744-750. doi:10.1016/.jtalanta.2010.10.037.

Zinn M, Witholt B, Egli T (2001) Occurrence, synthesis and medical application of bacterial polyhydroxyalkanoate. Adv Drug Deliv Rev 53:5-21. doi:10.1016/ S0169-409X(01)00218-6.

doi:10.1186/2191-0855-1-17

Cite this article as: Pantazaki et al: Simultaneous polyhydroxyalkanoates and rhamnolipids production by Thermus thermophilus HB8. AMB Express 2011 1:17. 